\title{
Orthodontic treatment - complications and preventive measures
}

\begin{abstract}
Orthodontic treatment aims at restoring correct occlusion and chewing function and improving the aesthetics of the dentition and facial esthetics of the patient. During treatment complications may occur. Most frequently observed complications have been described in the paper.

There role of the orthodontist in the therapeutic process and the principles on which doctor- patient cooperation should be based in order to achieve a therapeutic success have been presented. Particular emphasis has been put to the importance of prevention of dental caries and periodontal diseases in orthodontic patients.
\end{abstract}

Keywords: orthodontic treatment, complications, prophylaxis.

DOI: $10.2478 /$ pjph-2014-0024

\section{INTRODUCTION}

The number of orthodontic patients, both juveniles and adults is steadily increasing. The treatment aims to restore proper occlusion and normal chewing function and to improve the esthetics of the dentition and facial esthetics of the patient. To achieve this goal a repeated multi-specialty dental care is necessary, requiring the cooperation of orthodontists with physicians in other dental specialties - dentistry, periodontics, surgery and prosthetics.

\section{Complications occurring in orthodontic patients}

In the course of orthodontic treatment a number of complications that are closely related to its specificity may occur. Often, after 4 weeks of constant use of a fixed orthodontic appliance, which consists of cemented on the tooth surfaces orthodontic brackets, white spots lesions on the enamel may appear [1].These lesions are often associated with poor hygiene around the retention elements, creating extra space conducive to adhesion of dental plaque [2]. A greater retention of the plague is favoured by arch wires with numerous loops and bends, additional arch wires, elastic ligatures, and not removed excess of bonding material, which is used for bonding the brackets [3]. In orthodontic patients also the $\mathrm{pH}$ of saliva changes to lower (more acidic), the composition of the bacterial flora changes as well as the buffering and cleansing properties of saliva decrease, which favors the accumulation of dental plaque [4]. It is necessary to use additional, besides toothbrush, specialized devices for oral hygiene - irrigators, single-tuft toothbrushes, bands, dental floss and interdental brushes. Clinically, a white spot is manifested as white, matte and opaque lesion. Within the enamel demineralization occurs. The outer layer is apparently undamaged, while the histology image shows visible pores which cause a change in the light refraction and thereby determine the characteristic appearance of spots [5,6]. Enamel affected by demineralization, because of its porosity, tends to absorb colors from foods and drinks consumed. The spots are initially milky-white, with time they change the color from dark brown to brown. White spot lesions may appear around the brackets, oval or semi lunar in shape, around the gums on the labial surfaces of teeth, typically the upper and lower lateral incisors, the lower canines and surfaces of the upper first buccal molars [7]. They have a regular shape, are sharply demarcated from the surrounding enamel and appear asymmetrically. They should be differentiated from changes occurring in fluorosis. Untreated lesions can lead to the development of dental caries, and the discolored ones - following color absorption from saliva - to formation of brown discolorations.



FIGURE 1. Advanced white spot lesions in a patient after the completion of orthodontic treatment and marginal periodontitis. 
Another complication of orthodontic treatment is root resorption of teeth. This phenomenon is undesirable, with high incidence, leading to permanent loss of dental hard tissues [8]. During orthodontic treatment there are changes in morphology and physiology of the periodontal tissues, in the alveolar bone, cement and periodontium [9]. It is believed that during orthodontic treatment two primary factors influence root resorption: mechanical - following orthodontic forces - too high and for too long period of time, and the biological factor - associated with the progress of the process and the changes during its course [10].

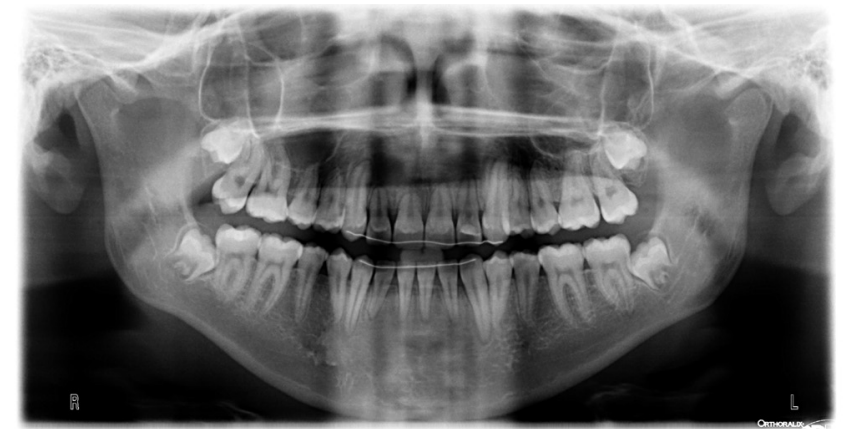

FIGURE 2. The patient after orthodontic treatment with resorptiontype lesions.

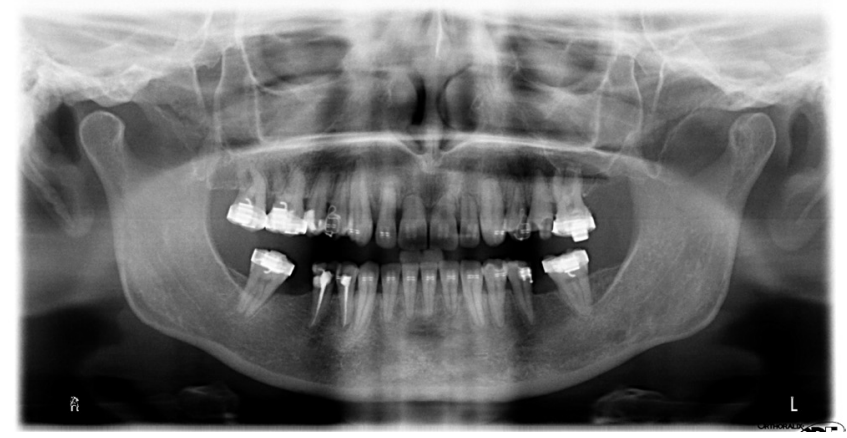

FIGURE 3. The patient during orthodontic treatment. Resorption of upper incisors.

A common phenomenon described in the literature is periodontitis of varying severity that occurs in patients receiving orthodontic treatment. During the entire orthodontic treatment periodontal status of the patient as well as the risk of periodontal disease should be assessed, and preventive measures should be performed. In the case of orthodontic patients frequently recession of the gums, bone atrophy - the formation of deep pockets and loosening of teeth because of alveolar bone resorption of inflammatory origin are stated, which results in increased mobility and pathological migration of teeth.



FIGURE 4. The patient during orthodontic treatment. Gingivitis and single white spot lesions.

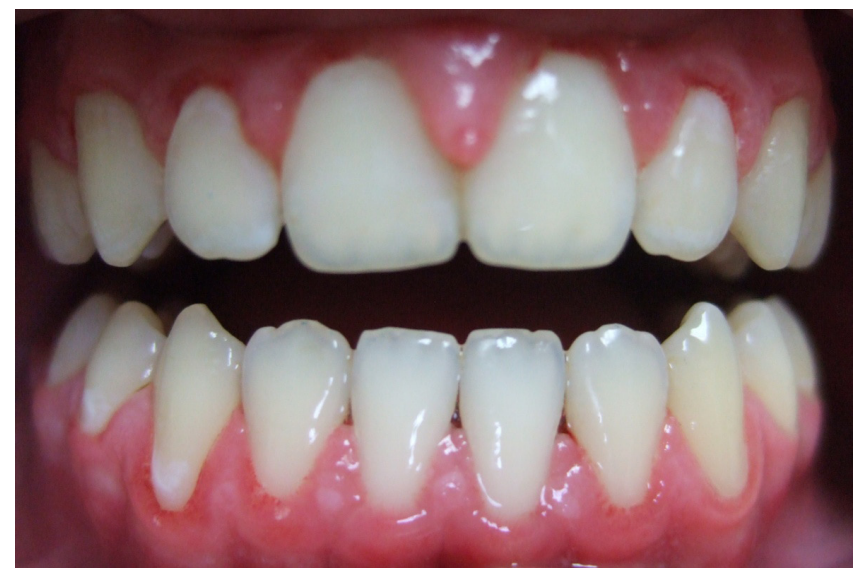

FIGURE 5a. Marginal periodontitis - swelling, redness of nodules with clinical bleeding at examination.

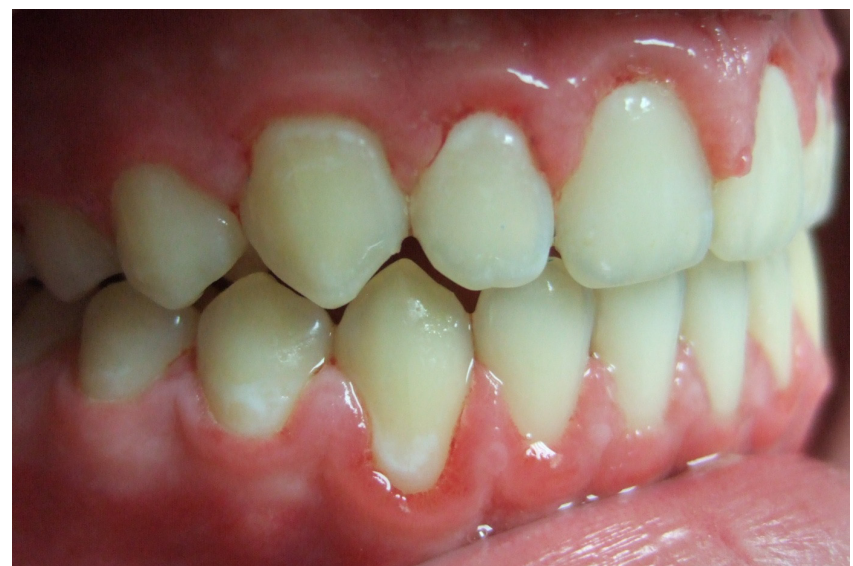

FIGURE 5b. Marginal periodontitis and white spot lesions.

Gingival recession is the exposure of the tooth root surface resulting from the loss of marginal periodontal tissues. The edge of the gum is retracted apically and the enameldentine border is exposed. Recessions may be accompanied by root caries, cavities of non carious origin, as well as dentin hypersensitivity. They can be caused by morphological as well as functional disorders of tooth and periodontal tissues. Risk factors include: parafunctions, abnormal occlusal contacts, incorrect tooth brushing technique and excessive accumulation of tartar [11-13]. The formation of the recession may be due to genetic predispositions - gingival (too thin gum), skeletal (dehiscence - too thin lamina), teeth-related (tooth crowding and inclination). Recessions can occur as a complication during orthodontic treatment, as well as the effect after its completion. Such changes may occur because of excessive forces in the course of orthodontic treatment, and improper planning and carrying out of treatment. Each vestibular setting of tooth in arch is associated with decreasing thickness of the gums and the bone, and hence the exposure to injury of periodontium increases, e.g. during brushing. In some patients, recessions are formed during anterior movement of the lower incisors, and the displacement in the direction of tongue raises the height of the gingiva and alveolar bone. It is crucial to carry out oral hygiene instruction conscientiously. Constant irritation of the tissues by the remains of food and accumulation of dental deposits favor the formation of the lesions and progression of destruction of the deeper layers of periodontium [14]. 


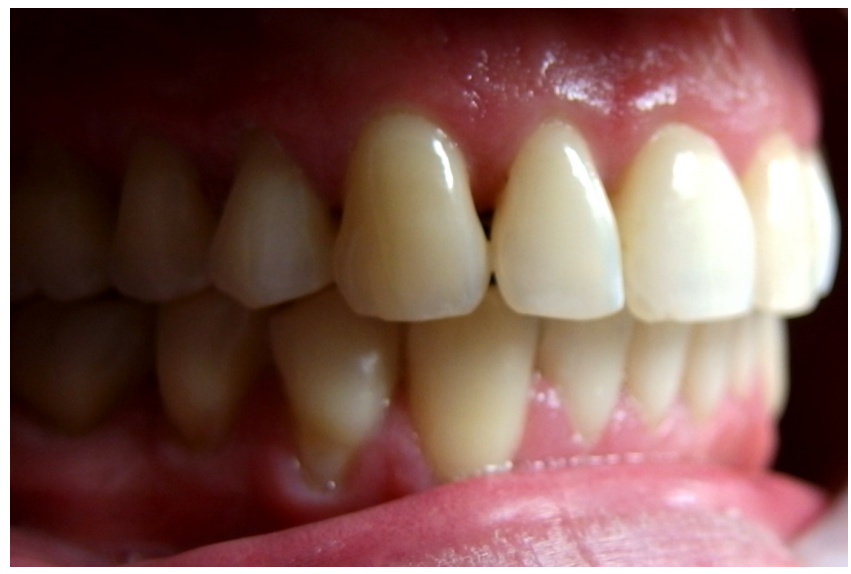

FIGURE 6a. Recession at tooth 44. Patient after orthodontic treatment, qualified for the gingivoplasty.

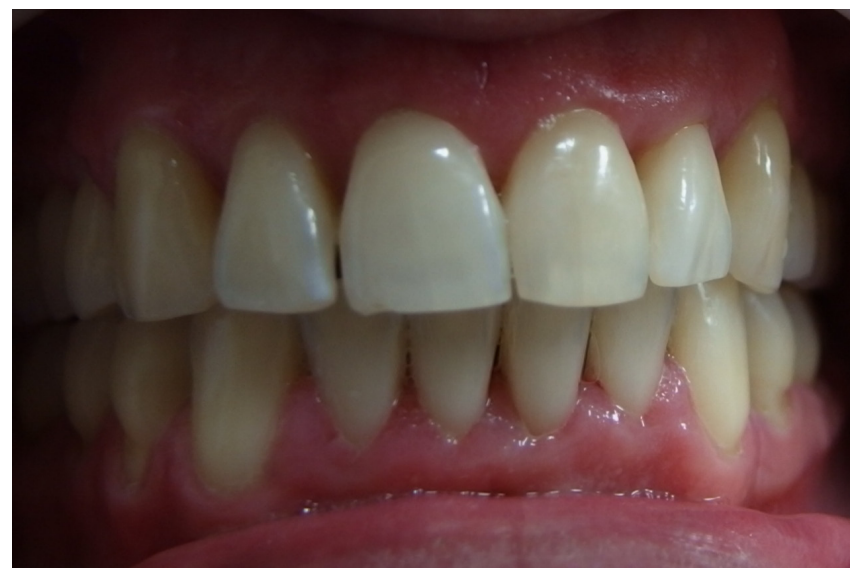

FIGURE 6b. Recessions at teeth 34, 44 .

A major problem is the mechanical injury of mucosa - stomatitis - because of biting or damage of mucosa and tongue by the retention elements of orthodontic appliance. This problem often concerns the patients in the first stage of treatment and is generally associated with the presence of severe dental defects. During treatment, when it comes to improving occlusal/dental relations and thus smaller exposure of mucosa to injury - the scale of the phenomenon is reduced. However, it should be noted that if left untreated, the changes can lead to bacterial, viral or fungal infections, hypertrophy of the mucous membranes, and even the development of premalignant changes $[15,16]$.

Latex being an element of orthodontic resins and the metals which are ingredients of brackets, arches and ligatures - chrome, copper, and especially nickel can cause allergic reactions in patients $[14,15]$. It is a type IV hypersensitivity which develops slowly (up to several years), and the reexposure to the allergen causes the reaction after 24-48 hours. Allergy is manifested by changes in the form of contact dermatitis, inflammation of oral mucosa and lips. At the point of contact with the allergen, erythema develops, accompanied by pain. Lips are red, cracked, swollen and dried. In contrast, in patients who wear cranial suspension lifts, contact dermatitis in the corners of the mouth may occur.

In the course of orthodontic treatment, many times there are: changes in the occlusion height - the rest position of the mandible, changes in centric and eccentric contacts, formation of traumatic nodes and the excessive load of the tem- poromandibular joints, which can lead to pain throughout the musculoskeletal apparatus in the head and neck. These changes are very common because of the high incidence in the population of bruxism - habitual teeth clenching, grinding. Parafunctions may affect the masticatory muscles, and also lead to morphological changes in the stomatognathic system, including the temporomandibular joints [17-19]. They can be classified according to the type of contacting tissues or tissues and foreign body into groups: DD (DensDens), DM (Mucosa-Dens), DC (Dens - Corpus Alienum), MM (Mucosa Mucosa-) [20]. Parafunctions undiagnosed before orthodontic treatment can lead to pain, complications and to prolonging the treatment and deterioration of occlusion. If not cured - the disorder may also cause relapse of defects in patients after the completion of orthodontic treatment.

In addition, the subjective feelings of the patients during orthodontic treatment are worth considering. These include restrictions on the consumption of certain foods, problems with speech, negative feelings in the use of retainers, hypersensitivity and pain. The latter are particularly pronounced after the follow-up visits and the treatment with cranial suspension lifts. All of the above symptoms significantly interfere with daily functioning of the patient.

\section{The role of the orthodontist in treating a patient}

Orthodontist should adequately prepare the patient for treatment by informing about the possibilities and limitations of the treatment, possible complications, as well as preventive measures, in which both the patient and the dental team will be involved. The treating physician is the one who should coordinate therapeutic procedures carried out, if necessary, in collaboration with other specialists. The first step is to perform a thorough dental examination of the patient - to assess the condition of teeth and periodontal tissues, as well as the therapeutic and prophylactic needs. Before deciding on the use of removable orthodontic apparatus or a fixed appliance, it is necessary to perform a complete photographic and radiological documentation (pantomogram, lateral image). The patient should have cured all carious cavities, as well as properly filled root canals in endodontically treated teeth. Periodontal treatment should also be completed. In case of unsatisfactory oral hygiene, it is necessary to perform professional prophylactic procedures (over-and subgingival scaling, sandblasting). Definitely oral hygiene instruction must be carried out and the patient must be advised to use suitable formulations for oral care (toothpaste, mouth rinses, gels with fluoride) [21,22]. It has been shown that the application of fluoride during each orthodontic visit helps reduce the risk of tooth decay by up to $40 \%$ [23]. In addition to the conventional preparations containing the fluorine compounds, sealants can also be used on smooth surfaces from which fluorine is released over a period of up to several weeks [24]. The doctor may also prescribe probiotic preparations in order to restore the natural flora in the oral cavity, which, after insertion of the appliance, usually changes in favor of cariogenic bacteria. There are also some modifications to diet and elimination or reduction of sugar in the diet. In the case of pathological changes in the course of orthodontic treatment, the doctor is obliged to inform the patient 
and offer specialist care in order to eliminate the causal factors and get complete recovery [25-27].

Orthodontist should control the entire course of the treatment, be aware of the risks and take appropriate steps to prevent complications. It is unacceptable to insert a fixed orthodontic appliance in the event of poor oral hygiene, dental plaque, periodontal inflammation, cavities.

\section{Cooperation between the orthodontist and the orthodontic patient}

Orthodontic treatment is often a long-term process. Cooperation of the orthodontist with physicians in other dental specialties, and above all with the patient, has a significant impact on the achievement of therapeutic success. Close cooperation of all persons involved in therapy helps minimize or eliminate the complications. The patient should be informed about the course of treatment, motivated to care for the oral cavity and be aware of the importance of treatments and activities necessary to maintain its proper state. It is the responsibility of the treating physician to examine accurately the patient's mouth during regular orthodontic visits, to perform professional preventive treatments according to the needs, teach proper oral hygiene with regard to the available products on the market designed for this purpose. It is very important to motivate the patient to maintain good oral hygiene and help in the selection of suitable formulations for this purpose. The patient should adhere to the doctor's instructions, and to prescribed by a doctor schedule of follow-up visits, pay special attention to proper oral hygiene (use the recommended preparations) and report problems related to the use of the orthodontic appliance.

\section{REFERENCES}

1. Staudt CB, Lussi A, Jacquet J, et al. White spot lesions around brackets: in vitro detection by laser fluorescence. Eur J Oral Sci. 2004;112:237-43.

2. Demling A, Heuer W, Elter C, et al. Analysis of supra- and subgingival long-term biofilm formation on orthodontic bands. Eur J Orthod. 2009;31:202-6.

3. Śmiech-Słomkowska G, Strzecki A. Wpływ leczenia aparatami stałymi na formowanie biofilmu w jamie ustnej. Forum Ortod. 2009;5(4):10417 .

4. Jabłońska-Zrobek J, Śmiech-Słomkowska G. Ryzyko próchnicy podczas leczenia ortodontycznego aparatem stałym. Czas. Stomat. 2005;58(7):514-9.

5. Mattousch TJ, van der Veen MH, Zentner A. Caries lesions after orthodontic treatment followed by quantitative light-induced fluorescence: a 2-year follow-up. Eur J Orthod. 2007;29:294-8.

6. Kidd EA, Fejerskov O. What constitutes dental caries? Histopathology of carious enamel and dentin related to the action of cariogenic biofilms. J Dent Res. 2004;83(Spec No C):C35-38.
7. Chapman JA, Roberts WE, Eckert GJ, et al. Risk factors for incidence and severity of white spot lesions during treatment with fixed orthodontic appliances. Am J Orthod Dentofacial Orthop. 2010;138:188-9.

8. Bielaczyc A, Herud B. Resorpcja korzeni zębów po leczeniu ortodontycznym na podstawie piśmiennictwa. Czas Stomatol. 1995;48(8):542-6.

9. Bielaczyc A, Herud B, Szafrańska A. Patogeneza resorpcji korzeni zębów w leczeniu ortodontycznym na podstawie piśmiennictwa. Czas Stomatol. 1996;49(3):200-5.

10. Filho PFG et al. Orthodontically induced inflammatory root resorptions: a case report. Dent Traumatol. 2006;22:350-3.

11. Dominiak M, Konopka T, Szajowski K. Recesje dziąseł w odniesieniu do potencjalnych czynników etiopatologicznych. Stomatol Współcz. 2002;9(2):22-8.

12. Gackowska M, Łuczkowska A, Kalukin J. Wpływ leczenia ortodontycznego na występowanie recesji tkanek przyzębia. Por Stomatol. 2006;8:12-6.

13. Górniak D, Grzywacz I. Zasady postępowania w skojarzonym leczeniu periodontologiczno-ortodontycznym pacjentów dorosłych. Ortod Współcz. 2002;4(2):39-42.

14. Pietrzyk M, Górniak D, Jabłońska E. Recesje przyzębia i higiena jamy ustnej u pacjentów leczonych aparatami stałymi i ruchomymi. Czas Stomatol. 1996;49(9):636-40.

15. Szymańska-Kubal D. Wybrane powikłania leczenia ortodontycznego aparatami stałymi i ruchomymi. Nowa Stom. 1999;3(1/2):31-40.

16. Pietrzyk M, Bielawska H, Górniak D. Wczesne powikłania leczenia ortodontycznego pacjentów młodocianych. Mag Stomat. 2002;12(10): 8-12.

17. Marbach J, Raphael KG, Janal MN et al. Reliability of clinician judgements of bruxism. J Oral Rehabil. 2003;30:113-8.

18. Panek H. Badania nad zależnościami czynnościowo-morfologicznymi układu stomatognatycznego ze szczególnym uwzględnieniem modeli funkcjonalnych zgryzu. Rozprawa habilitacyjna. Wrocław: AM; 2002.

19. Winocur E, Gavish A, Volfin G, et al. Oral motor parafunctions among heavy drug addicts and their effects on signs and symptoms of temporomandibular disorders. J Orofac Pain. 2001;15:56-63.

20. Siemińska-Piekarczyk B, Zadurska M, Biedrzycka E, et al. Etiologia i objawy kliniczne bruksizmu u dzieci i młodzieży na podstawie piśmiennictwa i własnych obserwacji. Czas Stomatol. 1998;51(1):4751.

21. Benson PE, Shah AA, Millett DT, et al. Fluorides, orthodotnics and demineralization: a systematic review. J Orthod. 2005;33:103-14.

22. Demito CF, Vivaldi-Rodriguez G, Ramos AL, et al. The efficacy of a fluoride varnish in reducing enamel demineralization adjacent to orthodontic brackets: an in vitro study. Orthod Craniofac Res. 2004;7:205-10.

23. Stecksén-Blicks C, Renfors G, Oscarson ND, et al. Caries-preventive effectiveness of a fluoride varnish: a randomized controlled trial in adolescents with fixed orthodontic appliances. Caries Res. 2007;41:455-9.

24. Benham AW, Campbell PM, Buschang PH. Effectiveness of pit and fissure sealants in reducing white spot lesions during orthodontic treatment: A Pilot study. Angle Orthod. 2009;79:338-45.

25. Bailey DL, Adams GG, Tsao CE, et al. Regression of post-orthodontic lesions by a remineralizing cream. J Dent Res. 2009;88:1148-53.

26. Lata S, Varghese NO, Varughese JM. Remineralization potential of fluoride and amorphous calcium phosphate-casein phosphopeptide on enamel lesions: An in vitro comparative evaluation. J Conserv Dent. 2010;13(1):42-6.

27. Willmot D. White spot lesions after orthodontic treatment. Semin Orthodont. 2008;14:209-19.

\section{Corresponding author}

Jolanta Szymańska

Chair and Department of Paedodontics, Medical University of Lublin

7 Karmelicka Str., 20-081 Lublin, Poland

E-mail: szymanska.lublin@gmail.com 